\title{
Detailed bioclimate analysis of Banja Koviljača (Serbia)
}

\author{
Goran Stojićević ${ }^{A}$, Biljana Basarin ${ }^{A}$, Tin Lukić ${ }^{A}$ \\ Received: January 21, 2016 | Revised: May 15, 2016 | Accepted: September 12, 2016
}

\begin{abstract}
The study presents the results of detailed bioclimatological analysis of Banja Koviljača. For the evaluation of bioclimate conditions significant for human health and activities, more than 100 indices have been developed. Indices based on human energy balance are proven to be the best for the evaluation of human thermal comfort. This paper analyses the variations and trends of the PET (Physiologically Equivalent Temperature) for Loznica meteorological station during the period 1961-2014. The fluctuations are analyzed for all seasons and annual values. In order to gain better insight into the variations of PET, seasonal and annual values of air temperature $(\mathrm{Ta})$, relative humidity $(\mathrm{RH})$, wind speed $(\mathrm{v})$ and cloud cover (CC) were investigated. Trends in the annual and seasonal time series were determined using Mann Kendal trend test. Additionally, trends in bioclimatological extremes were determined. The results indicated that statistically significant increasing trends in annual and seasonal values of PET exist and that in the future the change in tourism season and recreation potential could change. The increase of these values could be connected to the increase in Ta, decrease in $\mathrm{RH}, \mathrm{v}$ and $\mathrm{CC}$.
\end{abstract}

Keywords: bioclimate, PET, Banja Koviljača, trend, Serbia

\section{Introduction}

The thermal comfort of humans plays a significant role in human health and activities, especially in tourism, recreation and sport. More than 100 indices, for the evaluation of bioclimatic conditions, were developed during the last century (Epstein, Moran, 2006). Some indices are usually called simple indices and they show the joint effect on the human organism of several, individual meteorological variables such as air temperature, wind speed, and relative humidity. These indices include Heat Index, Humidex and Effective temperature. They are based on empirical research but on the other hand some are established on theoretical considerations (Blazejczyk, et al., 2012). Other group is comprised of indices that are derived from heat budget models. These indices take into consideration the conditions of heat exchange with the atmosphere (stress) as well as the physiological response of the hu- man organism (strain) (Blazejczyk, et al., 2012; Havenith, 2001; Parsons, 2003).

In order to maintain the function of inner organs and brain, it is crucial to preserve body core temperature within a narrow range around $37^{\circ} \mathrm{C}$. The temperature of skin and extremities can vary widely which represents one of the mechanisms to keep heat production and heat loss in equilibrium (Błażejczyk, et al., 2012; Epstein, Moran 2006).

One of the indices that take this complicated mechanism of body heat production and loss into account as well as the meteorological parameters is Physiological Equivalent Temperature (PET). PET was developed on the Munich Energy-balance Model for Individuals (MEMI) and uses the well-known unit for temperature $\left({ }^{\circ} \mathrm{C}\right)$, which makes the results easier to interpret and understand (Höppe, 1999; Matzarakis, et al., 1999). The PET $\left({ }^{\circ} \mathrm{C}\right)$ is defined as a combination of

\footnotetext{
A Department of Geography, Tourism and Hotel Management, Faculty of Sciences, University of Novi Sad, Trg Dositeja Obradovića 3, Novi Sad, Serbia

* Corresponding author: Biljana Basarin, e-mail: biljana.basarin@gmail.com
} 
aspects that deliver the equivalent temperature of reference environment characterized by vapour pressure of $12 \mathrm{hPa}\left(50 \%\right.$ at $\left.20^{\circ} \mathrm{C}\right)$ and still air $(0.1 \mathrm{~m} / \mathrm{s})$, at which the reference person maintains heat balance with core and skin temperature equal to those under the conditions being assessed (Höppe, 1999).

During the last 100 years there has been an increase in global mean temperature between $0.4^{\circ} \mathrm{C}$ and $0.8^{\circ} \mathrm{C}$ (IPCC 2007). But, also the overall warming was found to be even steeper during the second half of twentieth century with a trend over the period 1979-2005 of more than $2.5^{\circ} \mathrm{C}$ per century (Brohan, et al., 2006; Smith, Reynolds, 2005). In Europe this trend was distinguished from 1979 onward (Klein Tank, Können, 2003; Moberg, Jones, 2005; Brunet, et al., 2006; Della-Marta, et al., 2007). Several studies concerning European seasonal warming trends suggest that there is an increase in winter temperatures in central and northern Europe while the increase in summer and spring is not significant (Klein Tank, Können, 2003; Luterbacher, et al., 2004; Smith, Reynolds, 2005; IPCC, 2007; Ballester, et al., 2010).

Bajat et al., (2015) conducted the spatial analysis of annual and seasonal temperature trends in Serbia during the period 1961-2010 using mean monthly data from 64 meteorological stations. The study showed that there are two periods in data, one before the change and the second after. Negative trends were observed for the period before the change year except for winter season, while there was more pronounced positive trend after the change (Bajat, et al., 2015).

The changes in bioclimatological indices were not studied so extensively. Zaninović and Matzarakis (2007) showed that in PET series for Hvar (Croatia), the warming trend occurs around 1980's. Also studies about future bioclimate conditions (2071-2100) based on scenarios of IPCC second report on emission (SRES) $\mathrm{A1F}$ and $\mathrm{B} 1 \mathrm{~A}$, which represent a worst and a moderate climate case, help identify the areas with extreme and uncomfortable thermal conditions and heat stress affections. It was shown that in many regions of the world, e.g. the Mediterranean and North America, changes in thermal perception by humans would outpace changes in air temperature. These results imply that the effects of climate change on human health and well-being have been underestimated in past studies, mainly because they were based on air temperature changes rather than changes in PET, which describes the effects of meteorological and thermo-physiological parameters (Matzarakis, Amelung, 2008).

The first results of biometeorological parameters for Vojvodina, North Serbia were given by Basarin, et al., (2014). Respective authors presented a detailed analysis of climate and weather for tourism purposes (for two special nature reserves in Vojvodina, "Gornje Podunavlje" near Sombor and "Carska bara" near Zrenjanin), including important parameters such as Physiologically Equivalent Temperature (PET) and Tourism Climate Index (TCI). Analysis and assessment of the climate tourism potential (PET analysis) at the investigated sites, for the period 1949-2012, showed that present summer conditions are already hot for several touristic activities. This was not only the case during summer (for PETavrg), but also in spring and in autumn (for PETmax and PET14).

This is why it is of great importance to study trends in bioclimatological indices as well as their extremes. The aim of this study is to analyze the variations and trends of PET at annual and seasonal scale as well as trend and variations of main meteorological parameters necessary for the calculation of PET (air temperature, relative humidity, wind speed and cloudiness).

\section{Material and methods}

Banja Koviljača is located in the Jadar region, in the northwestern part of Serbia (Figure 1). It belongs to Loznica municipality and is one of the oldest spas in our country, with the long tourism tradition (Gajić, Vujadinović, 2010). Mean annual temperature for the meteorological station Loznica is $11.6^{\circ} \mathrm{C}$, with July being the hottest and January being the coldest month.

For the calculation of PET daily meteorological data from Loznica ( $\left.44^{\circ} 33^{\prime} \mathrm{N}, 19^{\circ} 14^{\prime} \mathrm{E}\right)$ meteorological station was used for period 1961-2014. RayMan model, modelling software (Matzarakis, et al., 2007; Matzarakis, Endler, 2010) was used to calculate PET values. It uses air temperature ( $\mathrm{Ta})$, relative humidity

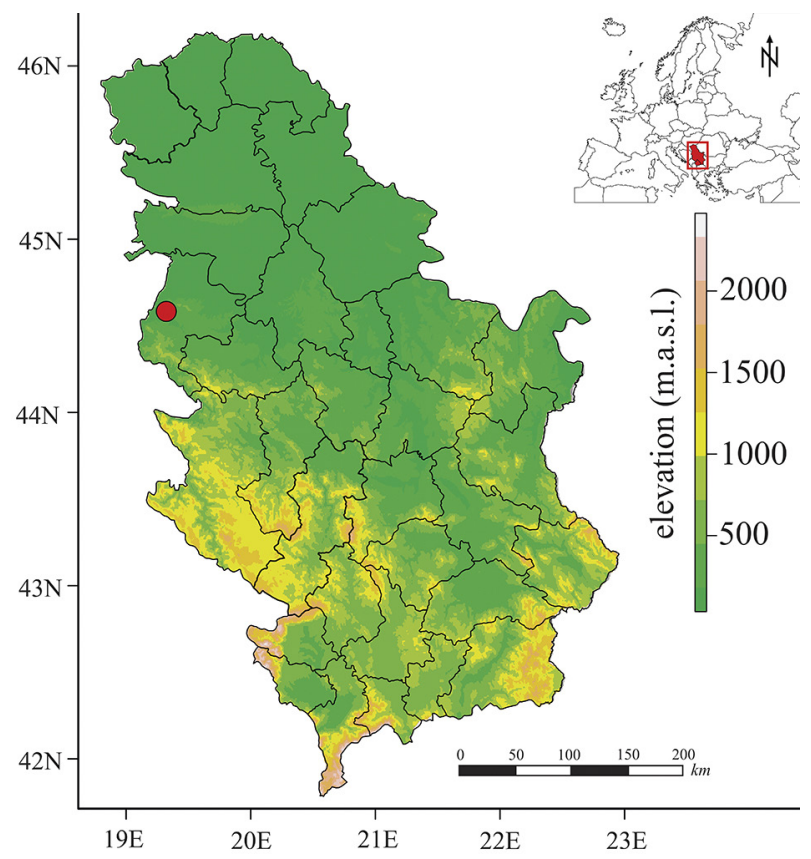

Figure 1. Map of Serbia and investigated site (dot) 
(RH), wind velocity (v), cloud cover (CC) and mean radiant temperature (Tmrt) as well as human parameters such as height, weight, clothing insulation and activity. The values of PET are graded as an index for showing thermal sensation felt by humans (Matzarakis, Mayer, 1996) (Table 1).

Table 1. Physiological equivalent temperature (PET) for different grades of thermal sensation and physiological stress on human beings (Matzarakis, Mayer, 1996)

\begin{tabular}{|c|l|l|}
\hline PET $\left({ }^{\circ} \mathrm{C}\right)$ & Thermal sensation & Physiological stress level \\
\hline$<4$ & Very cold & Extreme cold stress \\
\hline $4-8$ & Cold & Strong cold stress \\
\hline $8-13$ & Cool & Moderate cold stress \\
\hline $13-18$ & Slightly cool & Slight cold stress \\
\hline $18-23$ & Comfortable & No thermal stress \\
\hline $23-29$ & Slightly warm & Slight heat stress \\
\hline $29-35$ & Warm & Moderate heat stress \\
\hline $35-41$ & Hot & Strong heat stress \\
\hline$>41$ & Very hot & Extreme heat stress \\
\hline
\end{tabular}

In order to present bioclimatic conditions, PET values are analyzed by means of the annual course of the 10-day mean values of thermal sensation at 7.00 a.m., 2.00 p.m. and 9.00 p.m. during the year. For this purpose, daily meteorological data from Loznica for period 1993-2014 measured at 7.00 a.m., 2.00 p.m. and 9.00 p.m were used.

Calculated daily PET values were used in order to obtain mean monthly and annual series. Also, based on daily Ta, RH, v and CC mean monthly and annual values were calculated. Short-term fluctuation is time series were removed using 11 year running mean. Trends in the annual and seasonal time series were determined using Mann Kendal trend test (Mann, 1945; Kendall, 1976). In order to gain better insight into the bioclimatological fluctuations at Banja Koviljača the extreme values of PET were calculated (Table 2). For warm extremes annual number of days with
PET above $29^{\circ} \mathrm{C}$ and $35^{\circ} \mathrm{C}$ thresholds were calculated as well as monthly maximum value of daily PET and percentage of days when PET>9oth percentile. For the percentile based extremes base period 1971-2000 was used, as one of the reference periods recommended by World Meteorological Organization (WMO). For cold extremes annual number of days with PET below $0^{\circ} \mathrm{C}$ and $-10^{\circ} \mathrm{C}$ were used as well as monthly minimum value of daily PET and percentage of days when PET $<1$ oth percentile. The number of days with comfortable thermal conditions was also calculated. Likewise, following Basarin et al., (2016) intensity and duration of heat and cold waves were computed (Table 2). In order to determine the presence of positive or negative trends in extreme values Mann Kendal trend test was employed.

\section{Results}

The different thermal sensations according to PET values at 7 a.m. and 2 p.m. and 9 p.m. in ten-day periods are shown in Figure 2a. The analysis of Banja Koviljača's 10-day mean PET values between 1993 and 2014 demonstrate that extreme cold stress may be experienced in morning and evening hours during the colder part of the year (from the end of October through the third ten-day period of March). The extreme cold stress is relatively less observed during afternoons. Better thermal comfort conditions are seen during spring and fall. The second half of April, May, September and the first half of October are characterized by PET values that seem to be comfortable mostly throughout the day. During summer, June, July and August, comfortable thermal conditions are experienced in the morning and late afternoon. During noon in these months, a hot stress can be seen (Figure 2a).

The relative frequencies for PET values divided into 11 classes are presented in Figure 2b. Specific class presents thermal conditions for ten-day intervals throughout the year during the period 1961-2014. Thermal

Table 2. Definitions of extreme PET indices used in this study

\begin{tabular}{|l|l|l|}
\hline PET0 & Annual count of the days when PET $<0{ }^{\circ} \mathrm{C}$ & Days \\
\hline PET-10 & Annual count of the days when PET $<-10^{\circ} \mathrm{C}$ & Days \\
\hline PETx & Monthly maximum value of daily PET & ${ }^{\circ} \mathrm{C}$ \\
\hline PETn & Monthly minimum value of daily PET & ${ }^{\circ} \mathrm{C}$ \\
\hline PET10p & Percentage of days when PET<10th percentile & Days \\
\hline PET90p & Percentage of days when PET $>90$ th percentile & Days \\
\hline PEThw & Annual count of days with at least 6 consecutive days when PET $>95$ th percentile & Days \\
\hline PETcw & Annual count of days with at least 6 consecutive days when PET<5th percentile & Days \\
\hline PET35 & Annual count of the days when PET $>35$ (extreme heat stress) & Days \\
\hline PET29 & Annual count of the days when PET $>29$ (heat stress) & Days \\
\hline PET & Annual count of the days when PET is between 18 and 23 (comfort range) & Days \\
\hline
\end{tabular}



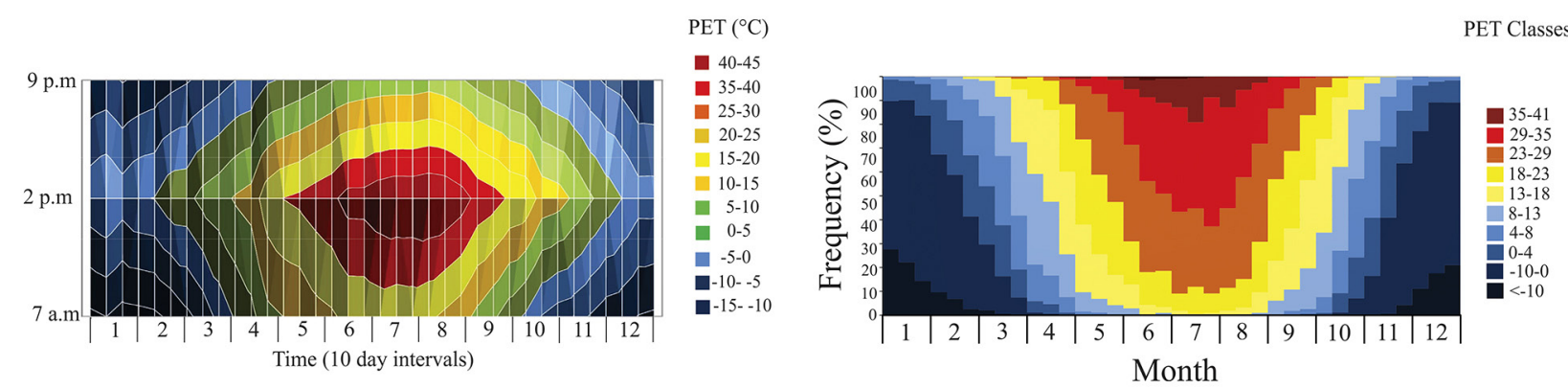

Figure 2. Bioclimate diagrams showing a) annual course of 10-day mean PET values at 7 a.m., 2 p.m. and 9 p.m for the period between 1993 and 2014; b) Relative frequency diagrams of mean daily PET for the period from 1961 until 2014

comfort occurs from the end of March until October according to mean daily PET values. PET values between 18 and $23^{\circ} \mathrm{C}$ with highest probability (>25\%) occur in the third ten-day period in April, May as well as in the end of September and October. PET classes that indicate cold stress $\left(<0^{\circ} \mathrm{C}\right)$ conditions can be observed even from the beginning of October to mid-April with highest frequencies (higher than $50 \%$ ) during the colder part of the year. Days with strong heat stress, defined as PET values $>35^{\circ} \mathrm{C}$ can be observed from the beginning of June until September with maximum frequencies ( 20\%) during July (Figure $2 b)$.

Mean annual PET values for the period 1961-2014 as well as PET anomalies are shown in Figure 3. Reference period used for the calculation of PET anomalies is period between 1971-2000, since this is the one of the current standard normal periods according to the WMO. Mean annual PET value for the reference period is $12.1^{\circ} \mathrm{C}$, while for the period $1961-1971$ it is $10.1^{\circ} \mathrm{C}$. During the last 15 years mean annual PET value is the highest, $13 \cdot 1^{\circ} \mathrm{C}$. Throughout the investigated period, highest mean annual PET value was observed in $2013,16.1^{\circ} \mathrm{C}$, while the lowest is measured in 1962 , $8.5^{\circ} \mathrm{C}$ (Figure 3).

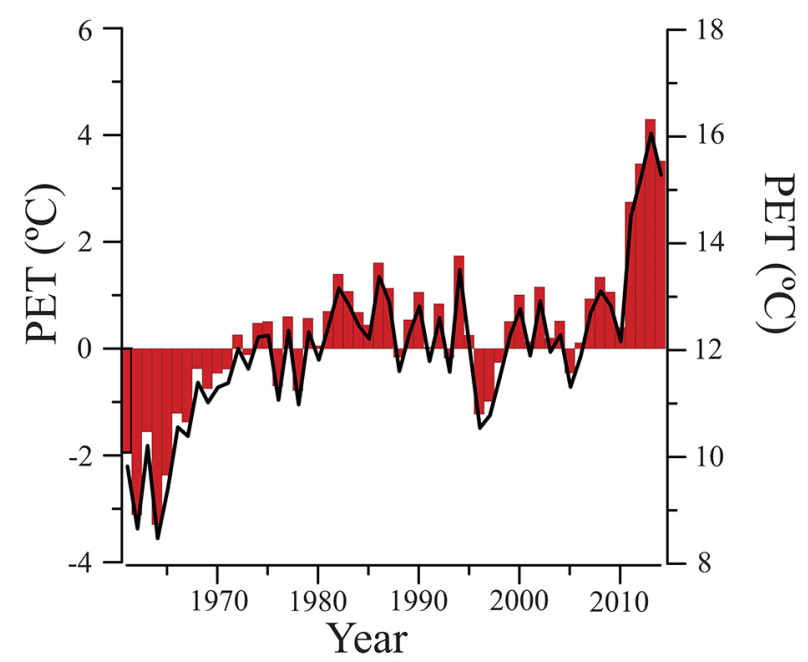

Figure 3. Mean annual PET values and PET anomalies derived from base period of the 1971-2000 for the investigated station
Negative PET anomalies could be observed from the beginning of the investigated period until 1973, with minimum values of $-3.3^{\circ} \mathrm{C}$. Years 1962, 1964 and 1965 are seen as the years with lowest annual PET values and largest negative anomalies. Since 1973, positive anomalies prevail with the exception of 1996 when largest negative anomaly of $1.6^{\circ} \mathrm{C}$ occurred in the second part of the investigated period. During the last six years largest positive anomalies are observed. The years with highest annual PET values and largest positive anomalies, higher than $3^{\circ} \mathrm{C}$, are 2013, 2014 and 2012 (Figure 3).

Figure 4 shows variations in mean annual PET values, Ta, RH, $v$ and CC. The fluctuations and trends of seasonal and annual values of PET as well as the meteorological parameters that influence the thermal comfort as Ta, RH, v and CC have been determined. Generally, mean annual PET values have increasing trend during the entire investigated period. The PET values show a visible warming since the late 1960's (Figure 4a). Running mean (bolder black line, Figure 4a) show increasing trend until 1987, when PET values start to decrease. This decrease lasted until 2001, when a sudden and large increase begin. Linear trend indicates an increase of $0.063^{\circ} \mathrm{C}$ per year, while the results of Mann Kendall trend test show statistically significant increasing trend of $0.059^{\circ} \mathrm{C}$ per year (Table 3). Seasonal values of PET have statistically significant increasing trend throughout investigated period (Table 3).

During the investigated period, largely, increasing trend in Ta is present (Figure 4b) Eleven year running average of Ta indicates that until 1981 the $\mathrm{Ta}$ is decreasing. Since then increasing trend is present, and linear trend indicates an increase of $0.04^{\circ} \mathrm{C}$ per year. Mann Kendall test results show that there is statistically significant increasing trend in mean annual $\mathrm{Ta}$ (Table 3). Seasonal values of Ta are rising during the last 50 years. This increase is also statistically significant (Table 3).

Decrease in mean annual values of RH could be seen during the entire investigated period (Figure 4c). Eleven year running average indicates that there is a slight increase in RH between 1973 and 1985, and then 
a.

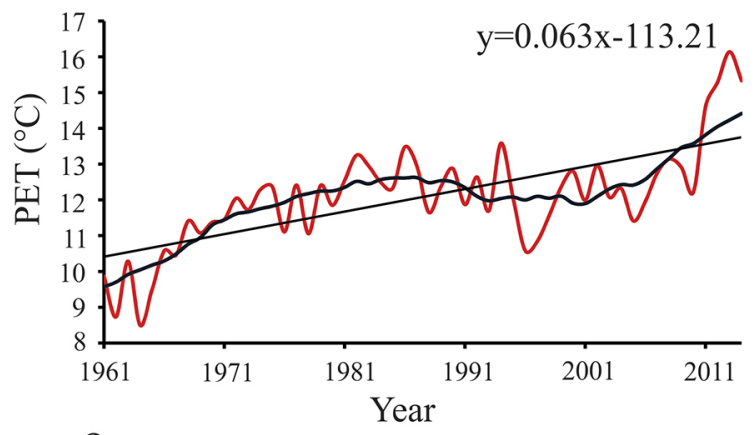

c.

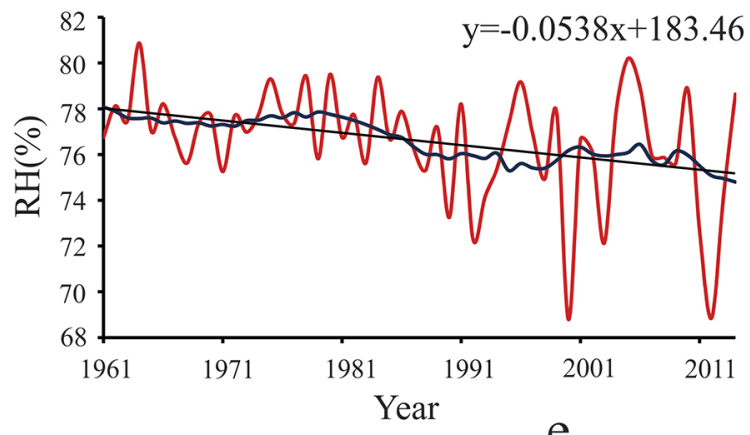

b.

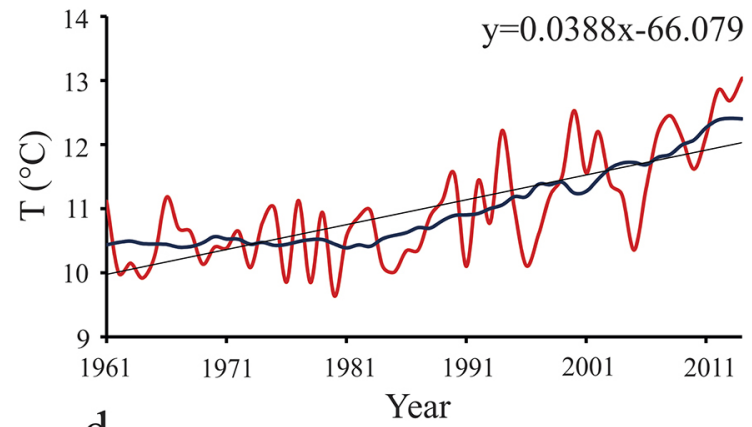

d.

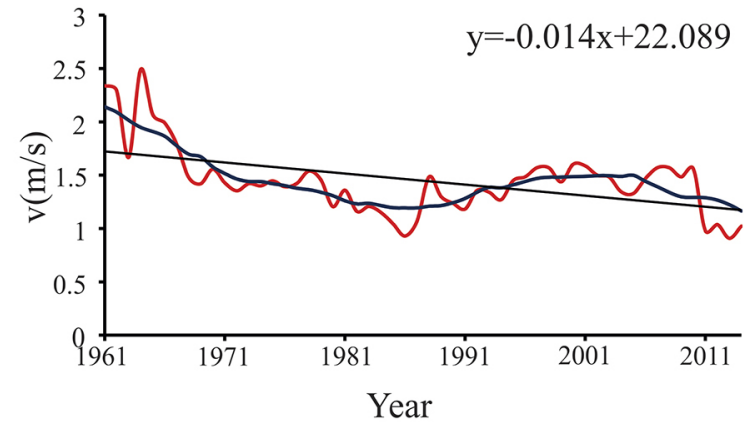

e.

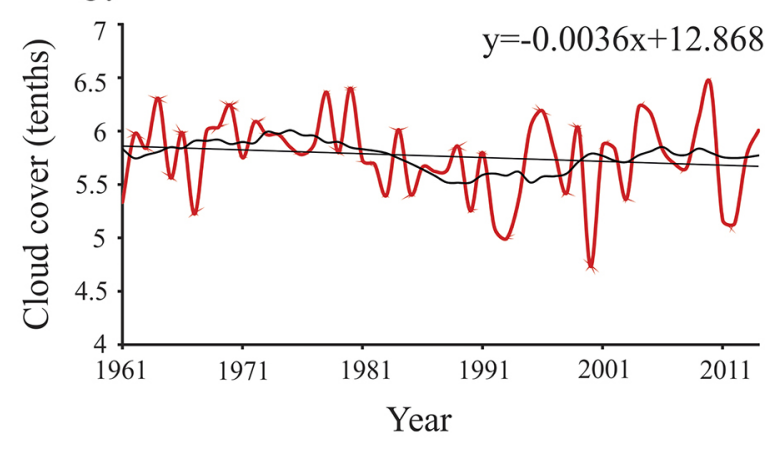

Figure 4. Variations of the a) mean annual PET; b) mean annual Ta; c) mean annual $\mathrm{RH}$; d) mean annual v; e) mean annual CC. Also shown are linear trends and their weighted 11-year moving average series during the period 1961-2014

insert RH before continue to decline. Statistically significant decrease in $\mathrm{RH}$ time series is present in annual, spring and summer values (Table 3 ).

As with $\mathrm{RH}$, wind speed is declining during the investigated 50 years (Figure 4d). From 1961 until 1986, wind speed is decreasing when it reaches its minimum annual value. After that period, it slightly in- creases until 2005 when it starts to decrease again. Mann Kendal trend test show that the decrease in annual and seasonal values is not statistically significant (Table 3).

Figure 4e shows variations in mean annual cloud cover at Banja Koviljača. During the investigated period only small fluctuations can be observed, with small

Table 3. The results of Mann Kendall trend test on annual and seasonal values of PET, Ta, v, RH and CC

\begin{tabular}{|l|c|c|c|c|c|}
\hline Parameter & Annual & Spring & Summer & Autumn & Winter \\
\hline PET & $0.05901^{\mathrm{a}}$ & $0.07^{\mathrm{a}}$ & $0.08 \mathrm{a}$ & $0.04^{\mathrm{b}}$ & $0.05^{\mathrm{a}}$ \\
\hline Ta & $0.04^{\mathrm{a}}$ & $0.04^{\mathrm{a}}$ & $0.05^{\mathrm{a}}$ & $0.02^{\mathrm{b}}$ & $0.04^{\mathrm{a}}$ \\
\hline $\mathrm{RH}$ & $-0.03806^{\mathrm{b}}$ & $-0.06^{\mathrm{b}}$ & $-0.08^{\mathrm{b}}$ & -0.01 & -0.001 \\
\hline $\mathrm{V}$ & -0.0072 & -0.01 & -0.007 & -0.008 & -0.003 \\
\hline CC & -0.004 & $-0.007^{\mathrm{b}}$ & -0.005 & 0.007875 & -0.00581 \\
\hline
\end{tabular}

a Statistical significance larger than $99 \%(p<0.01)$

${ }^{b}$ Statistical significance between $95 \%$ and $99 \%(0.05>p>0.01)$

c Statistical significance between 90 and $95 \%(0.1>p<0.05)$ 
a.

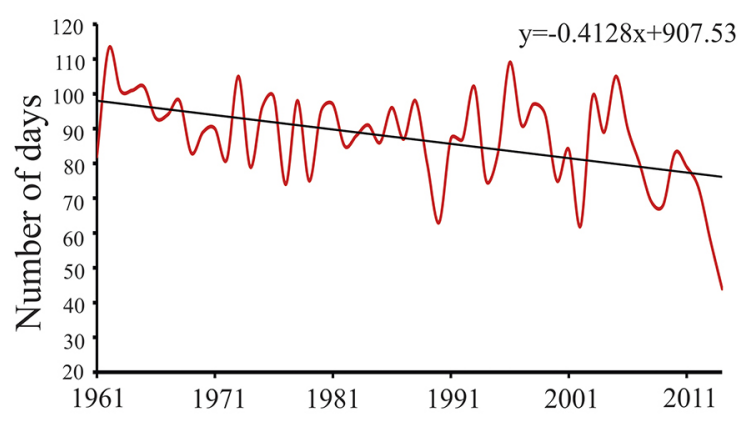

c.

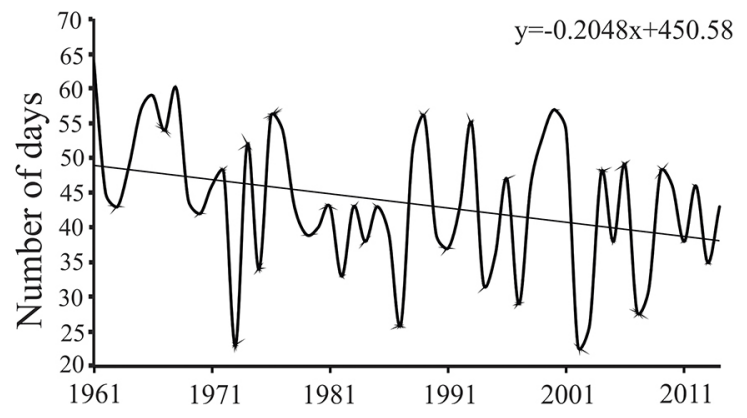

b.

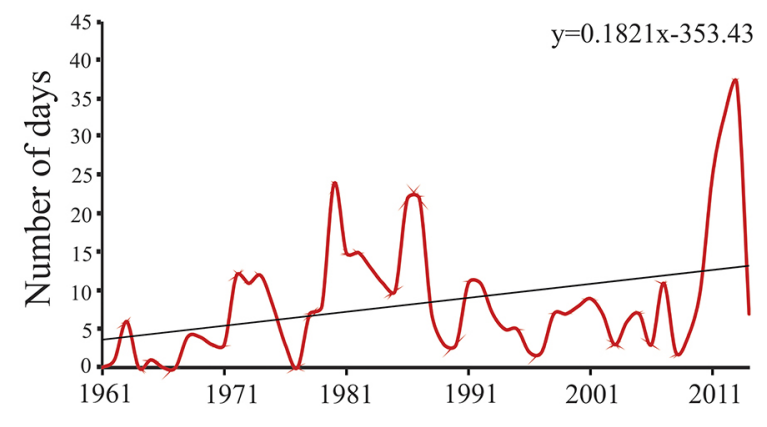

d.

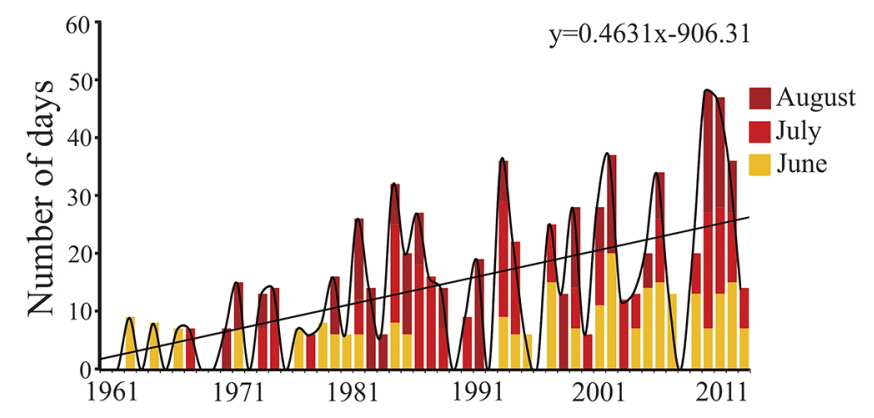

Figure 5. Number of days with a) $\mathrm{PET}<0^{\circ} \mathrm{C}$; b) $\left.\mathrm{PET}>35^{\circ} \mathrm{C} ; \mathrm{C}\right) 18^{\circ} \mathrm{C}<\mathrm{PET}<23^{\circ} \mathrm{C}$; d) heat waves. Also shown are linear trends

increase in the beginning of the time series and small decrease during the period 1981-2014 (Figure 4e). During the last 50 years statistically significant trend was not detected in annual as well as seasonal values ( Table 3$)$.

\section{Cold extremes (PETO, PET-10, PETcw, PETn)}

Annual number of days with $\mathrm{PET}<0^{\circ} \mathrm{C}$ is generally decreasing. The lowest number was detected in 2014, only 64 days, while the highest is seen in 1962, 113 days (Figure 5a). Mann Kendall trend test showed that every year there are 0.39 days less with $\mathrm{PET}<0^{\circ} \mathrm{C}$ (Table 4).

Similarly, days with extreme cold stress (PET<-10) are declining. This decline is steeper, with the highest number of days in 1962 (45 days), while in 2013 there were no days with extreme cold stress. The decrease in extremely cold days is statistically significant (Table 4).

Cold waves, defined as six and more consecutive days with PET below 5\% (Basarin, et al., 2016), are getting rare. The duration of cold waves indicates that the longest cold wave prevailed in Banja Koviljača during 1963, with January being the coldest month. On the other hand, statistically significant decreasing trend was not detected (Table 4).

In contrast to other cold extremes monthly minimum value of daily PET is increasing every year, but this increase is not statistically significant (Table 4).

\section{Warm extremes (PET29, PET35, PEThw, PETx)}

Annual number of days with extreme heat stress is rising every year. The highest number of days with $\mathrm{PET}>29^{\circ} \mathrm{C}$ was in 2003 , more than 60 , while the lowest was detected in 1961, only 9. The results of the Mann Kendall trend test indicate that there is a statistically significant increase in number of days with $\mathrm{PET}>29^{\circ} \mathrm{C}$, and that every year there are 0.44 extremely warm days more (Table 4 ). On the other hand, the increase in number of days with $\mathrm{PET}>35^{\circ} \mathrm{C}$ is not statistically significant (Figure 5b, Table 4).

The intensity and duration of heat waves is shown in Figure $5 d$. The threshold for the calculation of heat waves is PET above 95\%. Based on this threshold it can be seen that the highest number of consecutive days with extreme heat stress was observed in 2011, for 48 days, in 2012, 47 days and in 2003, 37 days. The hottest month according to this analysis was July (Figure $5 \mathrm{~d}$ ). The increase in duration of heat waves during last 50 years is statistically significant and indicates that every year there are 0.44 heat waves more (Table 4).

Similar to PETn, monthly maximum value of daily PET is rising, but the increase does not have statistical significance (Table 4 ). The number of days with PET values between $18^{\circ} \mathrm{C}$ and $23^{\circ} \mathrm{C}$ that correspond to comfort range are decreasing every year for 0.22 days, and this decrease is statistically significant (Table 4). 
Table 4. The results of Mann Kendall trend test on extreme values of PET for the period 1961-2014

\begin{tabular}{|l|c|c|c|c|c|c|c|c|c|}
\hline & PET-10 & PET0 & PET29 & PET35 & PET & PETx & PETn & PEThw & PETCW \\
\hline trend & -0.19 & -0.39 & 0.44 & 0.11 & -0.22 & 0.04 & 0.03 & 0.44 & -0.33 \\
\hline$p$ value & 0.01 & 0.00 & 0.00 & 0.25 & 0.05 & 0.79 & 0.32 & 0.00 & 0.14 \\
\hline
\end{tabular}

\section{Discussion}

Statistically significant increasing trends in annual and seasonal values of PET indicate that in the future the change in tourism season and recreation potential could change. The increase of these values could be connected to the increase in $\mathrm{Ta}$, decrease in $\mathrm{RH}, \mathrm{v}$ and CC. Statistically significant increase in Ta begun in 1989 according to the analysis done on 64 meteorological stations in Serbia (Bajat, et al., 2015). The model they used in the analysis estimated temperature decrease of 0.01 to $0.87^{\circ} \mathrm{C}$ per decade until 1989 when it begins to increase. The increase was estimated to be 0.18 to $3.62^{\circ} \mathrm{C}$ per decade. The increase was found to be statistically significant (Bajat, et al., 2015). The statistically significant increase in Ta for Banja Koviljača found in this study is in a good agreement with the studies done for Serbia as well as for Europe. In the recent studies it was found that the increasing trends in Ta in Europe started since 1970's (Balling, et al., 1998; Klein Tank, et al., 2002). Also, Gurevich et al., (2011) reported that the increase in Ta in Israel started in the late 1980's while in Italy the changes in the trend of Ta happened in 1981 (Toreti, Desiato, 2008). For Belgrade, Unkašević and Tošić (2005) found that the increasing trend in Ta occurred in 1975.

The decrease in RH in annual and seasonal values found in this study is in good agreement with the results of Gocić and Trajković (2013) who found that the RH values for Serbia are declining for all seasons. They also reported the decrease in wind speed for all seasons for the entire territory of Serbia (Gocić, Trajković, 2013).

The changes in meteorological parameters that influence PET values indicates that the changes in temperature have the greatest influence on fluctuations of PET. Decrease of v, RH and CC amplify the influence of the increasing trend of $\mathrm{Ta}$ on thermal comfort in Banja Koviljača.

Detailed analysis of climate extremes has recently been done on regional as well as on global scale. One of the first global studies was done by Frich et al., (2002) who found that the ice days are decreasing but on the other hand the number of days with $\mathrm{Ta}$ above $95 \%$ is increasing. Studies done since the IPCC report (2007) mainly support the conclusions from the report. It was concluded that the number of extremely cold days and nights as well as frost days is declining since 1960's (Brown, et al., 2008; Ballester, et al., 2010). In Europe the number of extremely warm days and nights is rising (Kurbis, et al., 2009; Bartholy, Pongracz, 2007).

The analysis of bioclimatological extremes was not that extensive. However, Zaninović and Matzarakis (2007) found that fluctuations of the bioclimate indices at Adriatic coast show a visible warming around 1950's and the increase is even more pronounced than in the temperature (Zaninović, Matzarakis, 2007). Also, Bleta et al., (2014) examined the changes in number of days with extreme PET and UTCI values at the island of Crete. They reported the absence of clear either increasing or decreasing trends during the 30-year period 1975-2004. This was explained by the complexity of the examined human thermal indices that are based on the energy balance of the human body and not on individual climatic parameters (Bleta, et al., 2014). Basarin et al., (2016) examined the duration and intensity of heat and cold waves in Novi Sad during the last 60 years. They found that the number of days with extreme heat stress as well as the heat waves is increasing since 1981. The analysis also showed that the heat waves are getting longer while the cold waves are shorter and their number decreases (Basarin, et al., 2016).

According to the trend presented in this study it could be expected that the extreme bioclimatological conditions will change dramatically. The values of PET calculated for the future (2071-2100) using the model results according to the IPCC second report on emission scenarios (SRES) $\mathrm{A}_{1} \mathrm{~F}$ and $\mathrm{B} 1 \mathrm{~A}$ indicate that the changes in PET will outpace changes in air temperature. It is highly likely that the effects of climate change on human health and well-being will de great and dramatic (Matzarakis, Amelung, 2008). Similar research has been done on a regional level. For example, the analysis of future climate conditions in Croatia indicated the increase in the mean temperature and PET. These changes will be seen earlier in coastal regions, especially southern Adriatic than in the continental part of Croatia. Also, when the days with $\mathrm{PET}>35^{\circ} \mathrm{C}$ for the base period (1961-1990) are compared with future periods $\mathrm{P}_{1}$ (2011-2040) and $\mathrm{P}_{2}$ (2041-2070) it could be seen that the increase will be $24 \%$ and $60 \%$ in the most eastern parts of the country (Brosy, et al., 2014).

Increasing trend for warm extremes and decreasing trends for cold extremes in Banja Koviljača are in correlation with similar studies. But in the future these vales could become even more pronounced. The study done by Kržič et al., (2011) indicated that the Ta in Serbia according to emission scenarios $\mathrm{A}_{1} \mathrm{~B}$ and $\mathrm{A}_{2}$ 
will rise from 2 to $4^{\circ} \mathrm{C}$. Also, the number of days with temperatures above $30^{\circ} \mathrm{C}$ will rise while the days with Ta below $0^{\circ} \mathrm{C}$ will decrease (Kržič, et al., 2011). These results indicate that in the future extreme bioclimatological events will change in Serbia and due to the potential negative effects on human health it is necessary to find the best mitigation strategies.

\section{Conclusion}

Climate change has boosted interest in climatic conditions in almost all economic sectors, as well as the tourism industry. Tourism industry as well as human health services are looking to find a way to stay informed, adapted and prepared for change. In the future, more frequent and intense extreme events, higher air temperature, more hot days, decreased daily amplitude, more droughts, and more floods are expected.

The aim of this study is to present the detailed bioclimatological analysis of popular tourist destination in Western Serbia, Banja Koviljača. The PET was calculated using daily meteorological data for Loznica meteorological station during the period 1961-2014. The results indicate that there are statistically significant increasing trends in annual and seasonal values of PET. These trends indicate that in the future the change in tourism season and recreation potential could change. The increase of these values could be connected to the increase in Ta, decrease in $\mathrm{RH}, \mathrm{v}$ and CC.

Bioclimatological warm extremes show statistically increasing trends, while the cold ones are decreasing. These results are in good agreement with similar studies. In the future extreme bioclimatological events will become more frequent in Serbia and due to the potential negative effects on human health it is necessary to find the best mitigation strategies.

\section{Acknowledgments}

This research was supported by Project 176020 of the Serbian Ministry of Education, Science and Technological Development and by Project 114-451-2080/2016 of the Provincial Secretariat for Higher Education and Scientific Research, Vojvodina Province.

\section{References}

Bajat, B., Blagojević, D., Kilibarda, M., Luković, J., Tošić I. 2015. Spatial analysis of the temperature trends in Serbia during the period 1961-2010. Theoretical and Applied Climatology 121, 289-301. doi:10.1007/soo704-014-1243-7.

Ballester, J., Giorgi, F., Rodó, J. 2010. Changes in European temperature extremes can be predicted from changes in PDF central statistics: a letter. Climatic Change 98, 277-284.

Ballester, J., Rodò, X., Giorgi, F. 2010. Future changes in central Europe heat waves expected to mostly follow summer mean warming. Climate Dynamics 35, 1191-1205.

Balling, R.C., Michaels, P.J., Knappenberger, P.C. 1998. Analysis of winter and summer warming rates in gridded temperature timeseries. Climate Research 9, 175-181.

Bartholy, J., Pongràcz, R. 2007. Regional analysis of extreme temperature and precipitation indices for the Carpathian Basin from 1946 to 2001. Global and Planetary Change 57, 83-95. doi:10.1016/j.gloplacha.2006.11.002.

Basarin, B., Kržič, A., Lazić, L., Lukić, T., Đorđević, J., Janićijević Petrović, B., Ćopić, S., Matić, D., Hrnjak, I., Matzarakis, A. 2014. Evaluation of bioclimate conditions in two Special Nature Reserves in Vojvodina (Northern Serbia). Carpathian Journal of Earth and Environmental Sciences 9,4, 93-108.

Basarin, B., Lukić, T., Matzarakis, A. 2016. Quantification and assessment of heat and cold waves in Novi Sad, Northern Serbia. International Journal of Biometeorology 6o, 139-150. doi:10.1007/soo484-0151012-z.

Blazejczyk, K., Epstein, Y., Jendritzky, G., Staiger, H., Tinz, B. 2012. Comparison of UTCI to selected thermal indices. International Journal of Biometeorology 56, 515-535.

Bleta, A., Nastos, P.T., Matzarakis, A. 2014. Assessment of bioclimatic conditions in Crete Island, Greece. Regional Environmental Change 14, 19671981.

Brohan, P., Kennedy, J.J., Harris, I., Tett, S.F.B., Jones, P.D. 2006. Uncertainty estimates in regional and global observed temperature changes: a new dataset from 1850. Journal of Geophysical Research 111, D12106. doi:10.1029/2005JDoo6548

Brosy, C., Zaninović, K., Matzarakis, A. 2014. Quantification of climate tourism potential of Croatia based on measured data and regional modeling. International Journal Biometeorology 58, 1369-1381.

Brown, S.J., Caesar, J., Ferro, A.T. 2008. Global changes in daily extreme temperatures since 1950. Journal of Geophysical Research: Atmospheres 113, Do5115. doi:10.1029/2006JDoo8091.

Brunet, M., Saladié, O., Jones, P.D., Sigrò, J., Aguilar, E., Moberg, A., Lister, D., Walther, A., Lopez, D., Almarza, C. 2006. The development of a new dataset of Spanish daily adjusted temperature series (SDATS) (1850-2003). International Journal of Climatology 26, 1777-1802.

Della-Marta, P.M., Haylock, M.R., Luterbacher, J., Wanner, H. 2007. Doubled length of west- 
ern European summer heat waves since 1880. Journal of Geophysical Research 112, D15103. doi:10.1029/2007JDoo8510.

Epstein, Y., Moran, D.S. 2006. Thermal comfort and heat stress indices. Industrial Health 44, 388-398.

Frich, P., Alexander, L.V., Della-Marta, P., Gleason, B., Haylock, M., Klein Tank, A.M.G., Peterson, T. 2002. Observed coherent changes in climatic extremes during the second half of the twentieth century. Climate Research 19, 193-212.

Gajić, M., Vujadinović, S. 2010. The state and perspectives of the development of spa tourism in the area of Jadar. Bulletin of the Serbian Geographical Society 90,3, 71-88.

Gocić, M., Trajković, S. 2013. Analysis of changes in meteorological variables using Mann-Kendall and Sen's slope estimator statistical tests in Serbia. Global and Planetary Change 100, 172-182.

Gurevich, G., Hadad, Y., Ofir, A., Ohayon, B. 2011. Statistical analysis of temperature changes in Israel: an application of change point detection and estimation techniques. Global Nest Journal 13, 215-228.

Havenith, G. 2001. An individual model of human thermoregulation for the simulation of heat stress response. Journal of Applied Physiology 90, 1943-1954.

Höppe, P. 1999. The physiological equivalent temperature-a universal index for the biometeorological assessment of the thermal environment. International Journal of Biometeorology 43, 71-75.

IPCC, 2007. Climate Change 2007: The physical science basis. Contribution of Working Group I to the fourth assessment report of the intergovernmental panel on climate change. Cambridge University Press, Cambridge.

Kendall, M.G. 1976. Rank Correlation Methods. 4th Ed. Griffin.

Klein Tank, A.M.G., Können, G.P. 2003. Trends in indices of daily temperature and precipitation extremes in Europe, 1946-99. Journal of Climate 16, 3665-3680

Kržič, A., Tošić, I., Djurdjević, V., Veljović, K., Rajković, B. 2011. Changes in climate indices for Serbia according to the SRES-A1B and -A2. Climate Research 49, 73-86.

Kurbis, K., Mudelsee, M., Tetzlaff, G., Brazdil, R. 2009. Trends in extremes of temperature, dew point, and precipitation from long instrumental series from central Europe. Theoretical and Applied Climatology 98, 187-195. doi:10.1007/s00704-008-0094-5.

Luterbacher, J., Dietrich, D., Xoplaki, E., Grosjean, M., Wanner, H. 2004. European seasonal and annual temperature variability, trends and extremes since 1500. Science 303, 1499-1503.

Mann, H.B. 1945. Nonparametric tests against trend. Econometrica 13, 245-259.

Matzarakis, A., Amelung, B. 2008. Physiologically Equivalent Temperature as indicator for impacts of climate change on thermal comfort of humans. In: M. C. Thomson, R. Garcia-Herrera, M. Beniston (eds.), Seasonal Forecasts, Climatic Change and Human Health. Advances in Global Change Research 30, Springer-Sciences and Business Media, 161-172.

Matzarakis, A., Endler, C. 2010. Climate change and thermal bioclimate in cities: impacts and options for adaptation in Freiburg, Germany. International Journal of Biometeorology 54, 479-483.

Matzarakis, A., Mayer, H., Iziomon, M.G. 1999. Applications of a universal thermal index: physiological equivalent temperature. International Journal of Biometeorology 43, 76-84

Matzarakis, A., Mayer, H. 1996. Another kind of environmental stress: Thermal stress. WHO collaborating centre for Air Quality Management and Air pollution Control. Newsletters 18, 7-10.

Matzarakis, A., Rutz, F., Mayer, H. 2007. Modelling Radiation fluxes in simple and complex environments - application of the RayMan model. International Journal of Biometeorology 51, 323-334.

Moberg, A., Jones, P.D. 2005. Trends in indices for extremes in daily temperature and precipitation in central and western Europe, 1901-99. International Journal of Climatology 25, 1149-1171.

Parsons, K.C. 2003. Human thermal environments: the effects of hot, moderate, and cold environments on human health, comfort and performance. Taylor\&Francis, London, New York, 2003.

Smith, T.M., Reynolds, R.W. 2005. A global merged land and sea surface temperature reconstruction based on historical observations (1880-1997). Journal of Climate 18, 2021-2036.

Toreti, A., Desiato, F. 2008. Temperature trend over Italy from 1961 to 2004. Theoretical and Applied Climatology 91, 51-58.

Unkašević, M., Vujović, D., Tošić, I. 2005. Trends in extreme summer temperatures at Belgrade. Theoretical and Applied Climatology 82, 9-205.

Zaninović, K., Matzarakis, A. 2007. Climatic changes in thermal comfort at the Adriatic coast. In: Amelung B, Blazejczyk K, Matzarakis A, (ed) Climate Change and Tourism: Assessment and Coping Strategies, 155-164. 